\title{
Command Responsibility for War Crimes
}

Citing the principle of command responsibility established by several post-World War II international tribunals, ${ }^{1}$ various commentators have suggested that high American military and political leaders were responsible for the many unordered war crimes committed by low-level troops in the Indochina War. ${ }^{2}$ The allegation is difficult to assess, partly because the post-war precedents left the principle's meaning unclear, and partly because the applicability of the precedents to American defendants in American courts is an unsettled issue of domestic law. In the only command responsibility prosecution brought against an American officer during the Indochina War, the court-martial of Captain Ernest Medina, the laws of war played only a minor and ambiguous role, and the defendant was acquitted. ${ }^{3}$ Thus the law on com-

1. Most of the tribunals which applied the principle are mentioned in a discussion of command responsibility in 15 UNited Nations WAR Crimps Commission, LaW Relokrs OF Trials of WAR Criminals 65-76 (H.M.S.O. 1945-1948) [hercinafter cited as UNLK]. That a commander is responsible for subordinate crimes does not of course relieve the subordinate perpetrators of their direct responsibility for the crimes. Though comb. manders are also responsible for subordinate crimes which they have directly ordercil, the term "command responsibility" refers throughout this Note only to liability for sub. ordinate crimes committed either under no order or under the order of someone other than the defendant-commander in question. This Note does not deal with a commander's duty to investigate and punish crimes after their commission. Nor does it deal with theories by which a commander who merely "passes on" an illegal order from his sil. periors to his subordinates may become directly liable for "ordering" subordinate crimes. On the latter problem, see U.S. DeI'T. OF the ARMY, InteknstionsL LAw 242 (l'ampli. No. 27-161-2, 1962).

2. For discussion of this suggestion, sec, e.g., T. TAYlor, NuREmuerg AND Vietnam: AN AMerican TRAGedy 172.82 (1970); Coburn \&" Cowan, The War Criminals Hedge "Thlicir Bets, Village Voice, Dec. 4, 1969; Hoopes, The Nuremberg Suggestion, TuE Wastunciron MoNThLy, Jan. 1970, at 18-21; Coburn \& Cowan, Letlers, id., Feb. 1970, at 4-5; Falk, Sonmy: War Crimes and Individual Responsibility, TRANSACTION, Jan. 1970, at 38.

3. Medina, company captain of the units involved in the My Lai Massacre, was charged with the "premeditated murder" of "no less than 100" Vietnamese Honcoill. battants, under Art. 118 (murder) of the Uniform Code of Military Justice [hercinafter cited as UCMJ], 10 U.S.C. 918 (1970). He was not charged with breach of the inter. national laws of war as recognized by Article 18, U.C.M.J., 10 U.S.C. $\$ 818$ (1970). After hearing the evidence, which indicated that Medina was not at the scenc of the massacre, though he was close-by and in radio communication with his troops, the military judge, Col. Kenneth Howard, dismissed the murder charge but instructed the jury on the lesser included Code offense of involuntary manslaughter, Art. 119(b)(1), UCMJ, 10 U.S.C. 919(b)(1) (1970). For conviction the judge required the jury to satisfy itself that Medina was "actually aware" that his men were "improperly killing non. combattants," and that, after accuiring such knowledge, he did not even attempt to halt the killing. Medina was acquitted on Sept. 22, 1971. On the acquittal and jury instruc. tions, see Bigart, Medina Found Not Guilty of All Charges on My Lai, N.Y. "Times, Sept. 23, 1971, at 1, cols. 3-4, and Hammer, Medina: Another of the My Lai (inilless, N.Y. Times, Sept. 26, 1971, § IV, at 6, cols. 1-7. See generally M. McCarriy, Mudini (1972). Whether the instructions accorded with accepted interpretations of involumtary manslaughter may be doubted. See note 60 infra. The instructions clearly diverged fron many interpretations of command responsibility found in international cases on the laws of war, see pp. 1278-87 infra, a point made strenuously by Taylor, The Course of Military Justice, N.Y. Times, Feb. 2, 1972, at 39, cols. 3-7. Whether Judge Howard should have conformed his instructions to the laws of war remains an open question, however, givell that Medina was charged only with UCMJ forms of homicide. See pp. 1289.91 infra and note 54 infra. If the Medina instructions are accepted as a proper reading of in. 
mand responsibility emerges from this war in a no more satisfactory state than it had reached after World War II.*

After analyzing command responsibility into its basic elements, and surveying the confusion of current law, this Note presents and defends a set of new command responsibility rules for prospective application in American courts, and briefly suggests the several ways in which these rules might become law.

\section{Current Law: Structure and Defects}

\section{A. International Precedents and the "Elements" of Command Responsibility}

The post-war tribunals rarely bothered to make a formal analysis of the offense they were creating, relying instead on brief and conclusory descriptions." Most "decisions" were attempts by a trial forum to marshal all the possible legal, moral, and evidentiary support for its verdict. Indeed many of the war crimes tribunals left no written record or opinion. ${ }^{6}$ There is no international legislature to update and clarify

voluntary manslaughter, and if American commanders are to be charged for their subordinates crimes only under UCMIJ forms of homicide, command responsibility will rarely attach for crimes neither witnessed nor ordered by the defendant-officer. Sec Tas lor. supra. For adverse comment on the Mfedina "precedent," see The Ifedina Acquillal (Editorial), N.Y. Times, Sept. 29, 1971, at 40, col. 1 .

4. The U.N. Commission recognized that the post-war cases left the offense in an unsettled state, see 4 UNLR 95. Commentary on the offense has been relatively sparse and has not proposed specific formulations of command responsibility which courts or legislatures might adopt. For a thorough and balanced discussion of alleged American war crimes in Vietnam, and of the possible responsibility of high-level officers for some of these, see O'Brien, The Law of War, Command Responsibility and Jietnam, $60 \mathrm{Gro}$. L.J. 605 (1972). For earlier commentary on command responsibility, see ArrLeMAs, MILtary Tribunals and International Crimes 303.05 (19j4); M. Greensids, Tue Modery Law of Land Warfare 478.86 (1957); A. Reet, Tue Case of General. Yaimasuita (1949): Arens, Vicarious Punishment and Wrar Crimes Prosecution: The Civil War or Alice Through the Looking Glass, 1951 W.Asu. UNiv. L.Q. 62 (1951); Fairman. The Supreme Court on Military Jurisdiction: Martial Rule in Hawait and the Yamashita Case, 59 Harv. L. Rev. 833 (1946); Snyder, Liability for Negalize Conduct, 35 VA. L. REv. 446 (1949); Speyer, Les Crimes de guerre par omission, REVUE DE vRorT PENAL ET DE CoIsINOLOGIE 903 (1949-50).

5. For example, the United States Supreme Court, in In re Yamashita, described command responsibility as "an affirmative duty to take such measures as [are] within his power and appropriate in the circumstances to protect prisoners of var and the civilian population." $32 T$ U.S. 1, 16 (1946). Note also the legal instruction given the tribunal in Trial of Meyer, 4 UNLR 97, 108:

[Has the accused] wilfully failed in his duty as a military commander to prevent, or to take such action as the circumstances required to endeasor to prevent the killing of prisoners ....?

These brief formulations are typical in their use of undefined legal terms, e.g., "wilfully" and "appropriate."

6. This is the case with many of the "minor" war crimes trials reported in UNLR. On the varying practices of tribunals in rendering judgments and opinions, see the UX: Commission's discussion at 15 UNLR 20. Even if well reasoned and fully reported, the cases would not constitute a body of "preccdent" in the usual sense. International criminal law recognizes treaties and customary practice, as vell as cases, and the principle of stare decisis is followed only loosely. See 15 UNLR 5-22. 
precedents and no international criminal court to enforce them or resolve their inconsistencies. ${ }^{7}$

Nonetheless, command responsibility has a formal structure worthy of analysis. A form of complicity ${ }^{3}$ through omission, it has four basic elements: status, mental standard, mental object, and the duty to intervene. Consider, for instance, the command responsibility rule in the U.S. Army Field Manual. ${ }^{\circ}$

[If a war crime is committed], [t] he commander of occupied territory is responsible if he has actual knowledge, or should have knowledge, through reports received by him or through other means, that troops or other persons subject to his control are about to commit a war crime, and he fails to take the necessary and reasonable steps to insure compliance with the law of war.

Status refers to the hierarchical relationship which a "commander" must bear to a "subordinate" for the former to incur a duty to intervene against the latter's crimes. Thus the Manual rule applies to a "commander of occupied territory" with regard to subordinates who are "troops or other persons subject to his control." The duty to intervene arises only at the point where the mental elements are satisfiedin the Manual rule, where a commander "should have knowledge" (minimal mental standard) "that [subordinates] are about to commit a war crime" (mental object). While the mental object identifies the event or prospect against which a commander is obligated to intervene,

7. The postwar international tribunals were merely temporary organs cstablished by the Allies to try Axis military and political figures for war crimes and for crimes against peace and humanity. The permanent International Court of Justice, the judicial organ of the United Nations, has no criminal jurisdiction over individuals. For a suggestion that the United Nations should nevertheless have investigated American war crimes in Vietnam, see Russell, My Lai Massacre-The Need for an International Investigation, 58 CALIF. L. REV. 703 (1970). On the international legal jurisdiction of national courts to enforce the laws of war against foreigners, see generally Carnegie, Jurisdiction over Violations of the Laws and Customs of War, 1963 BRIT. YEAR BOOK INT'L LAW 402 (1969).

8. The term "complicity" must be loosely construed here. First, since death is typlcally a permissible punishment for any war crime before an international tribunal, the classification of criminal parties has no necessary significance for potential penalty. Second, the classification of criminal parties varies among different nations' systems of domestic criminal law, and it cannot be assumed that international law incorporates any single classification. Third, it is logically possible to consider command responsibility as an inchoate crime, e.g., to find a commander responsible for allowing a high risk of crime to develop among his subordinates, even though no subordinate crime was actually committed. While no postwar case expressly recognized this possibility, neither did any case expressly foreclose it. Finally, the commander's liability is not always dcrived from the liability or potential liability of a criminal subordinate; it may, rather, flow directly from duties owed by the commander to the victims of the crimes. See note 13 infra.

9. United States Dép't of the ARMy, Field Manual 27-10: Tile Law of Land WARfare, para. 501 (1956). The Manual rule no doubt attempts to restate international law, and provisions from military manuals are "persuasive," though not "binding" statements of law before international tribunals, see U.N. Commission at 15 UNLR 21, but the rule is quoted here only to illustrate the element scheme suggested in the text. 
the duty to intervene itself indicates in what way, or how vigorously, the commander must intervene. Thus the Manual rule provides that he "take the necessary and reasonable steps to insure compliance with the law of war."

\section{Status}

The post-war cases permit only broad generalizations concerning the status relationship necessary for intervention duties to arise. First, command responsibility is not peculiar to military officers, but may also apply to police officials, civilian administrators, and cabinet officials. ${ }^{10}$ Second, staff officers and advisors with no operational authority over the criminal subordinates in question have no affirmative duty to repress their crimes. ${ }^{11}$ Third, under certain circumstances, a "commander" may apparently be liable for crimes of persons over whom his authority by national law or bureaucratic practice is limited or nonexistent. Thus, war crimes by military personnel were imputed to cabinet ministers having no authority in national law over military or prisoner of war (POW) affairs; ${ }^{12}$ and commanders in charge of occupied territory or of POW's were found responsible for protecting helpless POW's and civilians from injury regardless of its source, not merely from "war crimes" or from the excesses of the commanders' subordinates. ${ }^{13}$

10. See, e.g., Trial of Schonfeld, 11 UNLR 63 (police officials); Trial of Pohl, 5 Truls of War Criminals Before the Nuremberg Military Tribunals Under Control Council LAw No. 10 (1946-49, USGPO 1952) at 1054 (defendant Mummenthey, a civilian adminis. trator) [hereinafter cited as TWC]. On the responsibility of civilian administrators and cabinet ministers, even those ministers unconcerned with military affairs, see JuDGMENT of the International Military Tribunal for the Far EAst, Nov. 4-12, 1948, at 28-32 (1949) [hereinafter cited as Tokyo JudgMent], discussed in Horvitz, The Toliyo Trial, 465 International CoNciliation 571, 579 (1950). [Because the Tokyo Judgment and the dissents and concurrences are rarely available even in major university libraries, reference to them will be accompanied by reference to secondary materials which quote or accurately paraphrase the originals.] The American President could also be lound guilty of command responsibility, for there is no "head of state" cxemption from var crimes liability. See, e.g., Nuremberg Charter, Art. 7; Tokyo Charter, Art. 6; and Allied Control Council Law No. 10, ATt. II-all reprinted in United Natioss War Cames Commission, History of THE UNITED NAtioNs WAR CRIMES CoMmission 271.72 (1948) [hereinafter cited as UN Histori].

11. See, e.g., Trial of List, 11 TWC 759, 1281-86; High Command Trial, 10 TWC 1, 11 TWC at 629-90.

12. The Tokyo Tribunal convicted and executed Hirota Koki of command responsibility for war crimes committed while he was Forcign Minister of Japan, vithout national legal authority to repress the crimes. Though Hirota had sought to have the criminality suppressed, he had accepted "assurances" from the War Ministry rather than making independent investigation of continuing reports of crimes. The Tribunal held that he had either to succeed at convincing the cabinet to suppress the crimes or to resign from the cabinet. Tokyo JUdGMENT, supra note 10, at 1160.61, discussed in R. Afisin, Victors' Justice: The Tokyo War Crimes Trial $71-72$ (1971).

13. High Command Trial, 11 TWC at 544-47; Trial of List, 11 TWC 759, 1260; ToKYo JUDGMENT, supra note 10, at 28-32, excerpted at 15 UNLR 72-74. See also Essen Lynching Trial, i UNLR 88. Cf. also In re Yamashita, 327 U.S. 1, 15 (1910). That af- 


\section{The Two Mental Elements}

Tribunals and commentators have typically divided command responsibility rules into those which require actual knowledge of the subordinate crime and those which admit constructive. knowledge. ${ }^{14}$ Once accomplishing this classification, analysis has usually ended.

While important, this distinction should not dominate interpretation of the offense, or even of its mental elements. ${ }^{15}$ When a rule creates a naked "duty to know"-as does the Army Manual's unadorned phrase "should have knowledge"10 - a tribunal may of course measure the duty against any normative test: e.g., a reasonable man test, or some weaker or stronger standard. Once this test is selected, however, constructive knowledge is subject to only two sensible interpretations. First, it may mean a duty to make reasonable (or other) inferences from actually known facts, a conviction implying that the mental object

firmative duties may be imposed because the defendant bears either a pertinent status relationship to subordinate perpetrators of criminal acts or a pertinent status rclation. ship to the victims of injurious acts may be important for determining U.S. treaty ob. ligations to create and enforce the offense of command responsibility against its own officers. The 1949 Geneva Conventions require the U.S. to legislate against and prosecule those who have "committed" or "ordered to be committed ... grave breaches" of the Conventions. Art. 129, Convention Relative to the Treatment of Prisoners of War of Aug. 12, 1949, 6 U.S.T. 3316, T.I.A.S. 3364, 75 U.N.T.S. 135 [hereinafter cited as POW Convention], and Art. 146, Convention Relative to the Protection of Civilian Persons in Time of War of Aug. 12, 1949, 6 U.S.T. 3516, T.I.A.S. 3365, 75 U.N.T.S. 287 [hereinafter cited as Civilian Convention]. Such language does not include failure to prevent or to suppress grave breaches committed by subordinates; nor is the offensc of com. mand responsibility itself a grave breach, for the latter-so far as homicide is concerned-is defined as "wilful killing." Art. 130, POW Convention; Art. 147, Civilian Convention. But the Conventions do mention protective duties owed to POW's and civilians. Art. 13 of the POW Convention classifies as a "serious breach ... [a] ny un. lawful act or omission by the Detaining Power causing death or seriously endangering the health of a prisoner of war in its custody" (emphasis added). Article 16 of the Civilian Convention obligates signatory nations to "protect [persons exposed to grave danger] against pillage and ill-treatment." Cf. Paust, Legal Aspects of the My Lai Incident: $A$ Response to Professor Rubin, 50 ORE. L. REv. 138, 149 (1971), and Röling, The Lut of War and The National Jurisdiction Since 1945, 100 RECUEIL DES COURS DE' L'ACNUEMIE DE DROIT INTERNATIONAL DE LA HAYE 323,381 (1960).

14. See, e.g., High Command Trial, 11 TWC at 543.45; Trial of Pohl, 5 TWC 195, 1011; UN Commission, 4 UNLR 95; Röling, supra note 13, at 380; Appleman, supra notc 4, at 305; Taylor, supra note 3.

15. Because, arguably, a commander found wrongfully ignorant of the subordinatc crime does not deserve conviction where legally valid excuses would have relieved him from intervening even if he had known of the crime, invocation of "constructive knowledge" does not allow a tribunal simply to ignore the definition of intervention dutics.

Further, a simple division of command responsibility rules between actual and constructive knowledge obscures a third possible mental standard: approval of, or intent to encourage, the subordinate crimes. By definition this standard reduces the interven. tion duty to a minimum, for a commander could not be convicted if he had in any way manifested his disapproval of the subordinate crime. But support for this mental standard is very sparse. While the High Command Tribunal occasionally noted that a particular defendant not only knew, "but approved of" the subordinate crimes, it did not suggest that approval was a necessary element for conviction. High Command 'Trial, 11 TWC at 568, 627. See also Trial of Kesselring, 8 UNLR 9. where a commander's responsibility for subordinate abuse of the commander's orders was charged under a theory of "incitement."

16. See p. 1276 supra. 
specified in the rule was thus reasonably inferable. Second, a duty to know may mean a duty to make reasonable (or other) investigation of actually known, "suspicious" facts indicating the possible existence of the mental object, a conviction implying that such an investigation would have apprised the defendant of the mental object.

To appreciate the importance of this distinction, suppose the mental object specified in a rule is the fact that "subordinate war crimes are occurring." Expecting that they will confront only unarmed civilians, a commander sends his troops into a village and monitors their progress from a two-way radio installation ten miles away. Over the radio, he hears sporadic gun fire and what might be either laughing or screaming. He does nothing. It happens that, within three minutes of this incident, his troops massacred all the civilians in the village. If the commander "should have inferred" the crimes from the gun-shot sounds, he is responsible for all the murders: He should have communicated immediate orders to cease shooting. If, however, he "should have investigated" the gun-shot sounds, these being merely suspicious facts, he might escape responsibility for some or all of the murders by showing that a reasonable (or other) investigation would have taken some time. By contrast, if the commander had had no radio communication with his troops when the murders occurred, and thus no arvareness of facts from which the crimes' occurrence might have been inferred or on which an investigation might have been based, conviction could not be founded on constructive knowledge.

If, in this last case, a tribunal nonetheless convicted on grounds the commander "should have known" about the crimes, it would actually be misreading, or rewriting, the mental objecl requirement. The tribunal would in fact mean: (a) Before sending his troops on the mission, the commander knew or should have known (by inference or investigation) that there was a risk or high likelihood his subordinates would commit war crimes-this risk being a new mental object; (b) Such knowledge of this risk raised a duty to intervene against it-e.g., by staying near a radio, by warning his men to behave correctly, by accompanying them into the field, etc.; (c) Had these intervention duties been met, the crimes would have been prevented or, at the least, detected and instantly repressed.

To use the term "constructive knowledge" in such a case deprives the concept of clear boundaries and wrongly implies that the choice between actual and constructive knowledge is the sole determinant of a rule's power to trace liability to very high-level commanders for unordered crimes committed by very low-level subordinates. In fact, as 
the example above shows, the stringency of a command responsibility rule turns largely on its specification of the mental object.

This may take three forms. First, the rule may impose intervention duties only after the commander has the requisite knowledge that a specific crime-particularized by place, time, perpetrator, and typeis occurring or is planned. Attaching constructive knowledge to this mental object makes little difference: High-level commanders will rarely know facts from which inference or investigation would suggest the occurrence or imminence of a specific low-level subordinate crime. Second, the rule may also impose intervention duties when the commander has the requisite knowledge that a subordinate group or unit is engaged in a criminal policy or organized routine, e.g., of torturing captured officers for information. Requisite knowledge of a criminal policy is, by definition, requisite knowledge that a certain type of crime will predictably occur under specifiable contingencies. It is unnecessary that the commander have known, or have had a duty to know, that any specific criminal incident-particularized by place, time, perpetrator, and type-was occurring or definitely about to occur; and it is not sufficient that the commander knew merely that the unit in question had a high "crime rate" or was generally unruly.

Third, a rule may impose intervention duties as soon as a commander realizes that subordinate crimes are, for whatever reason, unacceptably likely to occur in the future. Here the mental object is the risk of future crime, and the rule must specify what degree or kind of risk is "unacceptable." With this mental object the distinction between actual and constructive knowledge virtually dissolves. Unless informed of the odds in a fair game of chance, a person never "actually" knows the likelihood of uncertain future events, but can only make an estimate on the basis both of facts known to him and of his awareness of ignorance or uncertainty about other relevant facts and circumstances. A tribunal can objectively determine the defendant's awareness or ignorance of particular facts and circumstances, but cannot objectively ascertain the inferences about risks which he actually drew from them. Thus a tribunal has little choice but to apply some normative test: Given the information he knew, should the commander have concluded that the risk of crime was unacceptable?

It is by specifying risks of crime as one of its mental objects that a rule can most readily create expansive intervention duties and hold high-level officers responsible for the unordered crimes of low-level troops. Risks of crime are often caused by precisely those large-scale factors which high-level commanders know about and directly control: 
Choice of strategies, tactics, or weapons; systems of recruitment and training; quality of leadership in the officer corps; the general state of discipline; etc.

The post-war tribunals reached no consensus in specifying the mental elements of command responsibility. Predictably, the cases adopting a mental object of specific crime (and rejecting any more expansive formulation) convicted only officers close in rank and geographic location to the subordinate perpetrators of crime, regardless of whether actual or constructive knowledge was chosen as the mental standard. ${ }^{17}$ Typically these tribunals were dealing with only a few defendant-commanders and a few subordinate criminal incidents. In the larger and more famous tribunals, the formulation of the mental object was necessarily broadened. Many defendant-commanders were joined in a single proceeding, each charged with liability for dozens, even hundreds, of subordinate crimes, and neither prosecutors nor judges were prepared to explore the actual knowledge, or duty to know, of each defendant regarding each specific crime. Thus the Nuremberg Subsequent Proceedings chose criminal policies as a mental object, ${ }^{18}$ vacillating only

17. In Trial of Tanaka, 5 UNLR 66, a Japanese general was charged with responsibility for the illegal trial and execution of an American POW' by the general's sub. ordinates while the general was on a leave of absence from his headquarters. The conviction was reversed on appeal, id. at 70 , becattse there was instufficient evidence the defendant had had "wrongful knowledge" of the subordinate crime charged. Had the appeals tribunal instead adopted a mental object of risks of future crime, the fact that the general apparently absented himself from headquarters without leaving behind adequate safeguards might have supported conviction. For an apparent application of this theory, see Trial of Sawada, 5 UNLR 1. The Trial of Schonfeld, II UNLR 63, also adopted a mental object of specific subordinate crimes. Subordinates of the accused, a German police commandant, had executed three allied JOW's in his absence. While the tribunal was instructed to convict if the accused "had reasonable grounds for supposing that his men were going to indulge in committing a war crime," id. at 70. the Judge Advocate explained that the accused "could hardly have reasonable grounds" if the subordinates had not "apprised" the accused ahead of time of their plans, id. at 71 . The tribunal was thus not free to decide that the accused knew there was a general risk of subordinate crimes.

In the Trial of Student, 4 UNLR 118, the Commander-in-Chief of German forces in the 1941 battle for Crete was charged with responsibility for a number of scattered subordinate crimes committed over $a$ two month period. The crimes did not constitute a policy or an established pattern, and there was no way-given his clevated rank and distance from the many battlefields-that the accuscel could have been aware of the occurrence or imminence of any of the specific crimes; thus conviction depended on adoption of risks of crime as a mental object. While the trial forum convicted on some counts, all convictions were reversed on appeal. In the Trial of Mejer, 4 UNLR 97, the accused commander was found responsible for subordinate crimes committed at his headquarters, probably because proper inferences from, or investigations of, known facts would have revealed the occurrence of these crimes to him, but he was acquitted of responsibility for subordinate crimes committed on a mission he did not accompany. even though his pre-mission instructions to those subordinates were inflammatory and clearly created a risk that the crimes would be committed.

18. Note, for instance, how the mental object is described in the Ohlendorf Tribunal's judgment on SS Brigadier General Jost:

The record clearly demonstrates... that as Chicf of Einsalzgruppe $A$, the defendant was aware of the criminal purpose to which that organization was put, and, as its commander, cannot escape responsibility for its acts. 
in the choice between actual and constructive knowledge as the mental standard.19 Other tribunals, however, went further and selected risks as a mental object. First, some tribunals convicted commanders who had created the risks by their own actions, e.g., by ordering especially aggressive action without stipulating that criminal abuses were not intended, ${ }^{20}$ or by launching a mission which, in the circumstances, involved a high risk of subordinate criminality. ${ }^{21}$ Second, commanders were required to infer from the past commission of crimes that the future occurrence of similar crimes was probable. ${ }^{22}$ Third, some tri-

4 TWC 1, 512 (emphasis added). Other Nuremberg Subsequent Procecdings adopting a \& mental object of criminal policies for command responsibility were: Trial of Brandi, 1 TWC 1; Trial of Pohl, 5 TWC 195; Trial of Milch, 7 UNLR 27 (reported also at 2 TWC); Trial of List, 11 TWC 759; High Command Trial, 10 TWC 1.

The rejection of risks as a mental object may be inferred from some of the results. Thus the Pohl Tribunal acquitted defendant Tschentscher, as SS company commander, of responsibility for his subordinates' participation in the murder of thousands of non. combattants in Eastern Poland and the Ukraine because "the participation of subordinates under his command ... was not of sufficient magnitude or duration to constitute notice to the defendant, and thus give him an opportunity to control their actions." 5 TIVC at 1011. Having earlier in his career instructed troop units on Nazl racial policies in occupied areas, id. at 1010, Tschentscher probably knew upon assum. ing command that there was a high risk his subordinates would become involved in illegal acts if he did not guard vigilantly against the possibility, but the Tribunal did not mention any duty to intervene against general risks of future crime. In the Trial of Milch, 7 UNLR 27, a high-level administrator was acquitted of responsibility for illegal medical experiments conducted by his subordinates on concentration camp in. mates. He was totally ignorant of the details of these experiments because he had totally delegated authority over the program to the subordinates, and his accuittal was grounded on the absence of "guilty knowledge." 7 UNLR at 36-37. He was aware of no particular "clues" of illcgal activities which would raise duties of inference or in. vestigation; compare cases creating duties to investigate or infer, note $19 \mathrm{infra}$. The total delegation itself might have been found to raisc unacceptable risks of crimc, a theory unexplored by the Milch Judgment but expressly rejected in Judge Phillips" concurring opinion. 7 UNLR at 62-63. On this theory, sec p. 1283 infra. In the Trial of Rauer, 4 UNLR 113, a mental object of risks was also rejected. The defendant was charged with three successive crimes committed by a unit of his subordinates. While the prosecution suggested that the accused's behavior prior to all three created a risk they would be committed, $i d$. at 115 , the tribunal convicted him of only the last two crimes, presumably on the theory that inference from or investigation of the first clcath would have revealed a subordinate criminal policy.

19. Compare High Command Trial, 11 TWC at 543.45, with Trial of Brandt, 4 UNLR at 92-93, 1 TWC I, and Trial of Pohl, 5 TWC 195, 1053.54, which imposed duties of inference from or investigation of known "suspicious" facts which were spelled out in the opinions.

20. See, e.g., Trial of Yamashita, 4 UNLR 1, 31 (order on suppressing gucrillas, allegation of prosecution); High Command Trial, 11 TWC at 560.61 (Barbatrossi Jurisdiction Order); Trial of Kesselring, 8 UNLR 9 (reprisal orders subject to abusc); but cf. High Command Trial, 11 TWC at 535, 628.29, involving acquittal of commanders who had issued or passed on legal orders raising a high risk of criminal abusc by subordinates. Orders themselves have been held illegal because they created high risks of subordinate crime. See Trial of Moehle, 9 UNLR 75. It is usually difficult to deter. mine whether a tribunal finds the order itself illegal or merely subject to risks of sub. ordinate criminal abuse which the commander has a duty to minimize.

21. See, e.g., Trial of Masao, 11 UNLR 56.

22. ToKyo JudGMENT, supra note 10, at 28-32, excerpted at 15 UNLR 74. Actually, the Tokyo Judgment required that commanders infer future risks from past crimcs of which they had only constructive knowledge, $i d$. This odd wedding of constructlve knowledge to a mental object of risks is unnecessarily confusing. A commander nced not be actually or constructively aware of particular suspicious facts, e.g., the commission 
bunals found that failure to supervise or keep a check on subordinates might raise unacceptable risks of crime. Thus, in a prominent conviction affirmed by the United States Supreme Court, the Japanese General Yamashita was found responsible for literally hundreds of crimes and criminal policies committed or engaged in by his subordinates in the Philippines. Because Yamashita maintained almost no communication with his subordinates, and there was no evidence he actually knew about these crimes, the case is commonly cited for the proposition that command responsibility incorporates "constructive knowledge." 23 This is a confused reading of the case. Yamashita apparently was aware of no particular facts which might raise a duty to infer or investigate specific crimes or criminal policies. Rather, the military commission and the Supreme Court held that his total ignorance, and the complete delegation of authority associated with it, themselves raised unacceptable general risks of future subordinate criminality, those crimes becoming chargeable to him as soon as they occurred.". By imposing duties of supervision and control, even where a commander is aware of no particular facts indicating that his subordinates are engaging in crimes, Yamashita accomplishes a greater expansion of command responsibility than would a mere recognition of "constructive knowledge."25 Going even further, the Tokyo Tribunal

of past crimes, to conclude that risks of future crimes exist. Rather, he can conclude from his very ignorance, detachment, and isolation that his subordinates, unchecked and unsupervised, are likely to slip into criminal activity. Sec pp. $1282-84$ \& note 79 infra.

23. See, e.g. UN Commission, 15 UNLR 65.76; Röling, supra note 13, at 379.80; and M. Greenspan, supra note 4 , at 483 . The Yamashita Trial is reported at 4 UNLR 1 , aff'd sub nom. In re Yamashita, 327 U.S. 1 (1946).

24. The prosecution concededly phrased its allegations in terms of wrongful ignorance. and the Judgment did mention a "duty to discover" subordinate crimes, 4 UNLR at 3 . but the trial record did not present clear proof that Yamashita was actually aviare of suspicious facts which would have triggered duties of inference or investigation into the criminal policies adopted by his subordinates. See summary of evidence, 4 UNLR at 18-23. Thus it does not appear that the tribunal found that Yamashita had failed to "follow up" any particular clue pointing to existing subordinate criminality, as had tribunals convicting other commanders for breaching duties to "know" about on going subordinate criminal policies. See cases cited note Ig supra. Rather, the tribunal found that Yamashita's failure to maintain general oversight and close control of his troops raised risks that they would get out of hand. He breached intervention duties, not duties of inference from or investigation of particular facts. The Supreme Court decision is consistent with this reading of the case. The Court said that a commander must "control" his troops so that subordinate crimes will not "result," 327 U.S. at 15, which indicates that risk of future crime, and not mercly the present occurrence of crime, raises intervention duties. Further, the Court's very vague holding makes no reference to constructive knowledge of existing crimes or policies: " [Yamashita had] an affirmative duty to take such measures as were within his power and appropriate in the circumstances to protect prisoners of war and the civilian population." Id. at 16. The military law precedents cited by the Court for this proposition involved instances where commanders had actual knowledge of the subordinate crimes changed to them. Id. at 16 n.3.

25. If read as a "constructive knowledge" casc, Yamashita merely holds that a commander is presumed to know of subordinate crimes which have become part of criminal policies engulfing almost his entire command. Since such pervasive and flagrant crim- 
found that unacceptable risks were raised by general supervisory defaults well short of Yamashita's nearly total abdication of command authority. ${ }^{26}$

Unfortunately, however, none of the tribunals adopting risks as a mental object attempted to summarize in general terms all the levels or kinds of risk which are unacceptable. Because each dealt only with the particular risk in the evidence before it, the law was left in an unsettled condition.

\section{The Duty to Intervene}

The vigor with which a commander must intervene against the specified mental object may be characterized in two broad ways. Either some general normative standard-such as "reasonably" or "diligently"-may be applied; or an absolute duty to eliminate the mental object may be established, subject to expressly defined excusing conditions which either extinguish the duty entirely or modify its demands.

Arguably, command responsibility is a type of criminal "negligence," so that a duty of "reasonable" intervention should be required. ${ }^{27}$ But, because the term "reasonable" simply invites a balanc-

inality is rare, and command ignorance of it more rare still, the holding would have few practical applications. By contrast, if read to impose general supervisory duties, the holding may result in command responsibility for subordinate crimes which are relatively few and scattered.

26. The Tokyo Judgment stated that cabinet members, military commanders, civilian administrators "concerned with the well being of POW's," and officials having "direct and immediate control" over POW's, have duties in'

establishing and securing the continuous and efficient working of a system ap. propriate... to secure proper treatment of prisoners and to prevent their ill. treatment . . [The Commander] has a duty to ascertain that the system is working and if he neglects to do so, he is responsible. He does not discharge his duty merely by instituting an appropriate system and thereafter neglecting to learn of its application.

TOKYO JUDGMENT, supra note 10, at 28-32, excerpted at 15 UNLR at 72-74. See also Trial of Sawada, 5 UNLR 1, where a commander was found responsible for crimes comnmitted by his subordinates while he was absent from his headquarters, the implication being that such absence creates unacceptable risks of subordinate criminality unless the commander has left careful instructions and delegated authority prudently. But sec Trial of Tanaka, supra note 17.

27. The U.S. Army Field Manual uses the ambiguous phrase "reasonable and neces. sary," see p. 1276. The term "necessary" is dropped in U.S. DEIT. OF THE ARMY, AKMY SubJeCr SCHEDULE No. 27-1, at 10 (1970). See also O'Brien, supra note 4, at 627-29, who contends that the "reasonableness" standard determines the contours of command responsibility according to the fact situations which prevailed in previous command xcsponsibility convictions. Id. at 629. Given that command responsibility cases are few and far between, and that questions of responsibility arise in an infinite number of conceivable fact situations, this suggestion is of doubtful practicality. In tort law, the reasonableness of a defendant's behavior is determined by a jury instructcd about the general attributes of a reasonable man, not about the fact situations which resulted in liability in "similar" cases in the past. RESTATEMENT (SECOND) OF TORTS $\$ 283$, Comment $C$. 
ing of social costs and benefits, ${ }^{28}$ consistent adjudication would require that judges roughly agree on the relative value of war crimes suppression, military success, and exact obedience to superior orders. It is doubtful that such a consensus exists even within a single nation's armed forces. ${ }^{29}$ In establishing standards of conduct, international war crimes law cannot merely incorporate recognized community norms, for none exist.

In fact, none of the tribunals invoked a reasonableness standard. Frequently the intervention duty was formulated in terms so ambiguous and question-begging as to establish no standard at all. ${ }^{30}$ Other tribunals imposed liability only if the defendant-commander did virtually nothing to eliminate the pertinent mental object; ${ }^{31}$ still others required more than "reasonable" intervention. 32

Nor were the cases entirely clear or consistent in identifying excusing conditions which might extinguish or modify the intervention duty. Defendants raised three types of excuses: lack of physical control over subordinates, lack of legal authority over subordinates, and military necessity.

Physical control: ${ }^{33}$ On assuming command, Yamashita inherited ill-

28. See, e.g., Restatement (Second) of Torts $\$ 283$, Comment E, \& \$\$ 291-93. The notion of reasonableness directs a jury member to a "community standard" of conduct in weighing the conflicting interests involved. Id. at $\$ 283$, Comment $C$.

29. O'Brien is more confident on this point, but docs not explain why:

Ernst Feilchenfeld, a respected international law publicist, once suggested ure necd

for a model "reasonable colonel" as the law of war counterpart to the common

law "reasonable man." Having taken all the rules and policy guidelines into account,

the judgment of command responsibility for war crimes turns on the standard of a

reasonable commander.

O'Brien, supra note 4, at 629.

30. In the Trial of Seeger, for instance, the tribunal was instructed as follows by the legal officer:

[I] $\mathrm{t}$ is for you with your members, using your military knowledge, going into the

whole of this evidence to say whether it is right to hold that General Secger ...

[was] required to do things which he failed to do and which amounted to a war crime.

4 UNLR 88. See also the instructions in Trial of Meyer, 4 UNLR 97, 107-08. The Supreme Court in Yamashita referred only to "measures ... appropriate in the circumstances," 327 U.S. at 16 , leaving formulation of a standard of conduct to the trial forum. The Military Commission had said that Yamashita had "failed to provide effective control of his troops as was required by the circumstances." 4 UNLR 1, 35. But, absent a standard of conduct, circumstances cannot "require" anything.

31. The High Command Tribunal, for instance, spoke of a "wanton, immoral dis. regard of the action of his subordinates amounting to acquiescence." 11 TWC at 544.

32. The Tokyo Tribunal, for instance, required a commander to "be at the same pains to ensure obedience to his orders [concerning protection of pow"s] as he vould in respect of other orders he had issued of the first importance." Tokro Judessent, supra note 10, excerpted at 15 UNLR 73 (cmphasis added). In requiring commanders to forestall the recurrence of war crimes, the Tribunal said responsibility would attach if commanders "failed to take such steps as were within their pouter to prevent the commission of such crimes in the future." Id. This, too, connotes a maximum cffort.

33. The excuse of physical inability, properly construed, is not necessarily involved simply because a defendant claims he could not do the "impossible." For instance, a defendant might claim he "could not" stop a subordinate crime because he u'as unatare 
trained and mutinous troops, and the Allied invasion of the Philippines cut his communications with many units. ${ }^{34}$ Neither the Supreme Court nor the military commission indicated whether he was implicitly acquitted of those crimes the risk of which he was powerless to eliminate. The prosecution had, however, argued that a powerless commander is not excused from duties but, rather, has a duty to offer his resignation. ${ }^{35}$ Conceivably, therefore, Yamashita holds that a commander who is incapable, for whatever reason, of controlling his subordinates must offer to resign his command, or suffer responsibility for ensuing crimes.

Legal authority: As noted above, ${ }^{36}$ international law occasionally attached commander "status" to a defendant whose authority to direct the criminal subordinates in question, or to countermand illegal orders issued to them by his superior or by independent officials, was limited by national law or by customary bureaucratic practice. Apparently such limits qualify-but do not eliminate-the defendant's duty to intervene against the subordinates' crimes. ${ }^{37}$ The cases do not, however, make clear just what intervention duties exist in such circumstances. Several tribunals acquitted commanders who had protested the illegal orders issued by their superiors. ${ }^{38}$ Attempts actually to countermand or correct illegal superior orders met a mixed judicial response, ${ }^{30}$ as did the

of $i t$, a claim which goes to the mental elements of the offense, and does not asscrt an excuse to the intervention duty. Similarly, that a defendant could not cffectivcly intervene at the time of the crime may be irrelevant if intervention was possible at the earlier point when he should have been aware of the risks of future crimc.

34. For General Yamashita's persuasive testimony and other evidence on this point, see 4 UNLR at $22-25$.

35. Id. at 33 .

36. See p. 1277 supra.

37. For instance, the High Command Tribunal concluded:

Under basic principles of command authority and responsibility, an officer who merely stands by while his subordinates execute a criminal order of his superlors which he knows is criminal violates a moral obligation under international law. By doing nothing he cannot wash his hands of international responsibility .... [A]ny silent acquiescence in their enforcement by his-subordinates constitutes a criminal act.

11 TWC at 512. The problem also arises where the order originates from a command hierarchy separate from that of the defendant-commander or where a commander is made liable for crimes committed by personnel who are not his subordinates under national law. Concerned that commanders were being asked to do the impossible in such circumstances, Judge Röling, dissenting in part at Tokyo, urged that the defini. tion of commander status closely track national law. The Far East Tribunal (Judgnent of B. Röling, Nov. 12, 1948), at 61-62, discussed in Horwitz, supra note 10, at 572. It is doubtful, however, that any general status definition applicable to a broad range of bureaucratic circumstances can entirely eliminate the possibility that intervention duties will be imposed on officers or officials who have only imperfect authority over the subordinates in question. Thus the law must make clear in what respects qualified authority alters a commander's intervention duties. On the related and much-discussed problem of a subordinate's duty to disobey superior directives ordering perpetration of crimes, see generally $Y$. Dinstein, The Defense of "Obedience to Suierion Ondens" in INTERNATIONAL LAW (1965).

38. See, e.g., Trial of Sawada, 5 UNLR 1; Velpke Children's Home Case, 7 UNLR 76; High Command Trial, 11 TWC at 555.58.

39. Compare High Command Trial, 11 TWG at 564.65, 625.29 (defendants Hollidt and Sperrle), with Trial of List, 11 TWC 759, 1297-1300 (defendant Dehner). 
proposition that commanders must protest or offer resignation. ${ }^{10}$ Oddly enough, no case addressed the equally important question whether a commander must violate, alter, or protest legal superior orders which, in the circumstances, frustrate or complicate his efforts to eliminate subordinate crime or an unacceptable risk of crime.

Military necessity: ${ }^{11}$ Without success, defendants argued that a commander preoccupied with planning offensive tactics, ; or with countering an enemy assault, ${ }^{43}$ has no time or energy remaining to control his subordinates. Also unsuccessful was the claim that military survival requires tactics or procedures involving a high risk of subordinate crime. ${ }^{44}$ Arguably, therefore, the laws of war require officers to retreat or surrender rather than pursue victory at a high risk of subordinate crime. $^{45}$

\section{B. Defects in American Law}

American courts require a congressional grant of jurisdiction to try violations of the laws of war. ${ }^{40}$ In making this grant-to general military

40. Compare High Command Trial, 11 TWC at 511-12 (defendant von Leeb) will the Tokyo Tribunal's demand that cabinet members (but not lower administrative officers or military commanders) resign if unable successfully to order the elimination of war crimes against POW's. ToKyo JubGMEN, supra note 10 , at 28.32 , excerpted at 15 UNLR 72-74. On the limited exculpatory impact of delayed resignation, see Trial of Ohlendorf, 4 TWC 518-20 (defendant Schulz).

41. None of the Tribunals used the term "military necessity" in discussing command responsibility, but the notion lurks in the background of any war crimes cese. See generally 15 UNLR 175, and O'Brien, Military Necessity in Intermational Law, 1 Woned PoLITY 138 (1957).

42. See, e.g., Trial of Rauer, 4 UNLR 113.

43. See, e.g., the argument of Yamashita's counsel before the Militan Commission, 4 UNLR at 24-25. Dissenting in Yamashita, Mr. Justice MIurphy argued that, under pres. sure of enemy assault, a commander should be held responsible only for specific crimes of which he had actual advance knowledge and which he had the power to prevent. 327 U.S. at 35,37 . While the majority presumably disagreed, it nowhere statcd that severe military difficulties might not have some influence on the duty to intervene against risks of future crime, or against known specific crimes and criminal policies.

44. In the Trial of Masao, II UNLR 56, a commander was held responsible for subordinate crimes committed on an evacuation march of POW's, the alternative to which was surrendering the prisoners to advancing allied forces. Yamashita issued bare orders to suppress guerilla activity, raising a high risk subordinates would abuse the orders, 4 UNLR at 31 , because an American invasion and a general breakdown of communications made elaboration of the order impossible, 4 UNLR at 18.23. Presumably, not to have issued any order would have amounted to accepting serious military setbacks at the hands of the guerillas. The Judgment did not disciss the issuc.

45. Lower-level officers, of course, may often be under superior orders not to retreat or surrender. The scope of "lack of legal authority" as an excuse in this situation remains an open question.

46. Crimes cognizable by federal courts must be enacted by Congress, rather than developed through a common law evolution. United States v. Hudson \& Goodwin, 11 U.S. (7 Cranch) 32 (1812). Arguably, however, the President himself, as Commander-inChief of the Armed Forces and as the nation's representative in roreign affairs, has constitutional authority to establish tribunals to try forcign nationals accused of international crimes against the United States or its citizens. Cf. Hirabajashi v. United States, 320 U.S. 81, 92 (1943) and Ex parle Quirin, 317 U.S. 1, 28.29 (1942), where the Court artfully avoids the issue. On the enforcement of international law in United 
courts-martial and, concurrently, to military commissions ${ }^{47}$-Congress had an opportunity to define in detail the offense of command responsibility (and, of course, other war crimes) and to provide for vigorous enforcement. Congress missed the opportunity and instead introduced new complications into the law of command responsibility.

Wholesale "incorporation": Though an exercise of Congress' power "to define and punish ... Offenses against the Law of Nations,"48 the grant of war crimes jurisdiction neither defines offenses nor specifies their punishment. Instead, Article 18 of the Uniform Code of Military Justice (UCMJ) states merely that "General courts-martial . . . have jurisdiction to try any person who by the law of war is subject to trial by a military tribunal and may adjudge any punishment permitted by the law of war." 40 Congress has simply "incorporated" the laws of war into the system of military justice. ${ }^{50}$ On command responsibility at least, this body of law is too inexact and inconsistent to influence military conduct. Consequently, wholesale incorporation raises problems of unconstitutional vagueness. 51 Precision is an especially important virtue where legal duties transcend common notions of moral obligation

States courts, see generally Dickenson, The Law of Nations as Part of the National Law of the U.S., 101 U. PA. L. REV. 26 (1952); Sprout, Theories as to the Application of International Law in the Federal Courts of the United States, 26 AM. J. INT'L LAw 280 (1932).

47. Article 18, U.C.M.J., 10 U.S.C. $\$ 818$ (1970).

48. U.S. ConsT., art. I, $\$ 8$, cl. 10.

49. Article 18, U.C.M.J., 10 U.S.C. $\$ 818$ (1970).

50. See Ex parte Quirin, 317 U.S. 1, 30 (1942).

51. A federal court has no jurisdiction to try crimes unless Congress has defined the offense with particularity. United States v. Hudson \& Goodwin, 11 U.S. (7 Granch) 32 (1812). Even when created by legislation, an offense is unconstitutionally vague if it fails to afford adequate guidance to law officers and fair warning to potential violators. See, e.g., Grayned v. Rockford, 408 U.S. 104 (1972); Papachristou v. Jacksonville, 105 U.S. 156 (1972); Coates v. Cincinnati, 402 U.S. 611 (1971).

The Supreme Court has upheld wholesale incorporation of the laws of war against a claim that common law offenses were thereby recognized without adequate definition, Ex parte Quirin, 317 U.S. 1 (1942), but the continued vitality of the decision is open to doubt. The vagueness doctrine has developed considerably since Quirin. Further, the laws of war have themselves grown much more complex and confused since the decision, aggravating the vagueness problem. See generally Kunz, The Ghaotic Status of the Laws of War, 45 AM. J. INT'L LAw 37 (1951). Concerning confusion in international notions of relational responsibility, see Wasserstrom, The Relevance of Nuremberg, I Phil. and Public Affairs 22 (1971). Quirin relied heavily on United States v. Smith, 18 U.S. (5 Wheat.) 153 (1820), cited in Quirin, supra, at 29. While holding that a statute outlawing "piracy" was a sufficiently detailed exercise of congressional power to "define and punish Piracies and Felonies committed on the high Seas, and Offences against the law of Nations," citing U.S. CoNST, art. I, $\$ 8$, cl. 10, Smith stressed that "the crime of piracy is defined by the law of nations with reasonable certainty," and suggested that wholesale incorporation of "Offences against the Law of Nations" would raise constitutional questions. 18 U.S. (5 Wheat.) at $157-60$. It can hardly be said that command responsibility, much less war crimes law generally, finds a reasonably ccrtain definition in the "law of nations." Cf. also Dynes v. Hoover, 61 U.S. (20 How.) 65, 82 (1857), which upheld congressional incorporation into the navy codc of all crimes "punished according to the laws and customs of the sea" on the theory-patently in. applicable to modern war crimes-that "what the crimes are, and how they are to be punished, is well known by practical men in the navy and army." 
and conflict with pressures for success in combat. "Incorporation" vests in the trial forum nearly unlimited discretion to define the offense, 32 a discretion typically exercised in an atmosphere of high emotion. Because, war crimes cases, like the wars which generate them, occur irregularly, judge-made common law has little chance to develop consistency and coherence.

Conflict with UCMJ offenses: Despite Article 18's incorporation of international law, American war crimes are customarily tried as violations of specific criminal provisions in the UCMJJ.53 Apparently, the prosecution has unfettered discretion to proceed either under these provisions or under Article 18's international law..$^{54}$

While the UCMJ's articles do not expressly mention command responsibility, the offense might conceivably be charged as a form of complicity in the subordinate's crime, as an inferior grade of homicide, or as the inchoate offense of "dereliction of duty."

52. The Supreme Court's role would be the minor one of determining that the trial forum, in setting standards for the offense, did not go beyond the international law of war as recognized by the United States. In re Yamashita, 327 U.S. 1, 13, 16.18. The Supreme Court is apparently reluctant to formulate international criminal law on its own, preferring to exercise a mere veto power over interpretations developed by lower military courts. Id. at 17-18.

53. Dep'T OF the U.S. ARMY, Fiedd MINuat, supra note 9, para. 507(b).

54. The fact that the UCMIJ makes a delict punishable under one of its express articles apparently does not deprive a military tribunal of jurisdiction to try the delict instead as a violation of some body of non-Code law, advanced by the prosecution, which the tribunal has jurisdiction to enforce. Cf. MIadsen v. Kinsella, 313 U.S. 341 (195I), and United States v. Gallagher, 21 C.Mr.R. 435 (1950). In drafting "charges" (i.e., an information), the prosecution will normally but need not specify which Code provision is purported to cover the defendant's delict. Manual for Counts Mantual, [cited hereinafter as MCMI], para. 27, at 6-3 (1969). See United States v. Shulz, 1 U.S.C.MI... 512, 4 C.M.R. 104 (1952). But, if the prosecution charges only under specific UCMI] criminal provisions, rather than under Article 18's "incorporated" international law, and if the prosecution throughout trial and appeal directs its evidence and argument only to those provisions, it would be, at the very least, extraordinary for the courts to convict the defendant of an offense against international law.

That international and specific code offenses might be in conflict has received little consideration. In Ex parte Quirin, the Supreme Court scemed to assume, without so stating, that the "Law of War" jurisdiction of military courts is intended solely for trial of enemy belligerents, the specific provisions of domestic military law being sufficient to cover all delicts by American military personnel. 317 U.S. 1, 28.29, 47. Cf. In re Yamashita, 327 U.S. 1, 7, 9. In originally recommending that courts-martial and military commissions have concurrent jurisdiction over violations of the "Law of War," Judge Advocate General of the Army Crowder suggested that such jurisdiction was needed over American military personnel only to try delicts cntircly unrecognized by specific provisions of United States military law. S. Rep. No. 229, 63rd Cong., 2d Sess. 53 , 98-99 (1914). Theories of command responsibility, however, exist woth in interuztional law and in specific UCMJ provisions. While this is also, of course, the case with more conventional "war crimes," such as rape and murder, the overlap there is of no practical significance, the international and military versions of the offenses being virtually identical.

55. Complicity through inaction is discussed in MCM, para. 156, at 28-4, which construes the definition of "principals" to crime given in Art. 77, U.C.M.J., 10 U.S.C. $\$ 877$ (1970). Involuntary manslaughter is discussed in MCM, para. 198b, at 28-46, construing the definition of the offense given in Art. $119(\mathrm{~b})(1)$, U.C.A.J., 10 U.S.C. 919(b)(1) 
would, like Article 18, involve the possibility of capital punishment or life imprisonment. Inferior grades of homicide and "dereliction" carry much lower maximum penalties. ${ }^{56}$

Complicity-through-omission requires that the defendant have had a "duty to interfere" with the crime. ${ }^{57}$ W.hile the command relationship does apparently raise this duty, ${ }^{58}$ the alleged accomplice must have been at the scene of the crime, must have approved of the crime's perpetration, and must have, through this approval, provided "encouragement" for the perpetration. ${ }^{59}$ As for involuntary manslaughter, the Manual for Courts-Martial's broad definition might be read as requiring a commander to eliminate a high risk that his subordinates will commit murder, but the Manual's illustrative examples of the offense do not even hint at such an interpretation. ${ }^{60}$ An officer has been convicted of negligent homicide for failing to stop a subordinate's crime, but the Board of Review, in reversing, indicated that an officer must have actual knowledge of the subordinate's crime before incurring a duty to intervene against it. ${ }^{61}$ Assimilating command responsibility to traditional notions of homicide is obviously a troublesome project. Officers have quite frequently been convicted of "dereliction of duty" concerning subordinate crimes. While typically the officer was present during the crimes and "did nothing," breach of general supervisory duties

(1970). Negligent homicide is discussed in MCM, para. 213f(12), at 28.80, the offensc being contained in the General Article, Art. 134, U.C.M.J.. 10 U.S.C. 984 (1970). Derc. liction of duty is discussed in MCM, para. 17/c, at 28-22, construing the offense created by Art. 92(3), U.C.M.J., 10 U.S.C. $\$ 892(3)$ (1970).

56. Complicity through inaction would render the commander a "principal . . . subject to the maximum punishment authorized for the commission of the [underlying] offense," which will often be capital. MCM, Table of Maximum Punishments, para. $127 \mathrm{c}$, at 25-10 n.1. Article 18 of the U.C.M.J. allows that war crimes may be met with "any punishment permitted by the law of war." 10 U.S.C. $\$ 818(1970)$. The rolc of capital punishment in United States courts is, of course, confused in the wake of Furman v. Georgia, 408 U.S. 238 (1972). The maximum penalties for involuntary manslaughter, negligent homicide, and dereliction of duty are 3 years, 1 year, and 3 months respectively. MCM, Table of Maximum Punishments, para. 127c, at 25.10 through 25.17.

57. MCM, para. 156, at 28-4.

58. See United States v. Rexroad, 34 C.M.R. 783, 786 (1963) and United States v. Waluski, 21 C.M.R. 46, 55 (U.S.C.M.A., 1956) (concurring opinion of Latimer, J.).

59. MCM, para. 156 , at $28-4$.

60. Involuntary manslaughter ... is an unlawful killing by culpable negligence ... Culpable negligence is a degree of carclessness greater than simple negligence .... Thus the basis of a charge of involuntary manslaughter may be a negligent act or omission which, when viewed in the light of human expcrience, might forcsec. ably result in the death of another, even though death would not, necessarily, be a natural and probable consequence of the act or omission.

MCM, para. 198b, at 28-46. But the Manual lists as examples:

conducting tarket practice so that the bullets go in the direction of an inhabited house within range; pointing a pistol in fun at another and pulling the trigger Id. ... and carelessly leaving poisons or dangerous drugs where they may endanger life."

61. United States v. Flaherty, 12 C.M.R. 466, 469 (1958). 
has occasionally been punished where subordinate crimes followed, ${ }^{02}$ and the Code criminalizes dereliction of any duty created by "custom of the service," an obviously elastic concept. ${ }^{03}$

In short, rather than resolving the conflicts in international law, the UCMJ supplements them with additional theories of command responsibility, also poorly formulated, and fails to indicate which provisions apply in which circumstances.

Misplaced prosecutorial authority: Normally, it is the commanding officer who decides when to convene courts-martial for prosecution of his subordinates. ${ }^{64}$ This procedure is manifestly unsuitable for enforcing rules of command responsibility. A commander will naturally hesitate to prosecute a subordinate officer for command responsibility, because such action would invite attention to his own behavior regarding the underlying subordinate crimes. ${ }^{05}$ By delegating prosecutorial discretion to military men without legal training, the system promotes inconsistent enforcement of any offense as vaguely formulated and technical as command responsibility. And the system provides no agency or individual-except the President himself-to investigate and prosecute cabinet members, civilian administrators, and military officers at the apex of the command hierarchy. ${ }^{00}$

62. See generally Avins, Military Leadership and the Law, 47 CALIF. L. REv. 828, $861-68$ (1959).

63. MCM, para. 171c, at 28-22. The Army has suggested that command responsibility is "as a minimum" punishable as a dereliction of duty. U.S. DEPT. OF TIE ARMr, ARury SUBJECT SCHEDULE, No. 27-1, at 10 (1970).

64. Art. 22, U.C.M.J., 10 U.S.C. \$ 822 (1970). The President and the pertinent service secretary also have convening authority. Arts. 22(a)(I) and (2), U.C.M.J., 10 U.S.C. \$ $822(a)(1)$ and (2) (1970). No convening authority resides in a commanding officer if he is the "accuser" of the defendant, Art. 22(b), U.C.AI.J., 10 U.S.C. $\$ 892(\mathrm{~b})(1970)$.

65. With prosecution authority lodged in the command structure, the offense of command responsibility will probably be met more frequently with informal adminis. trative sanctions than with formal charges. The division commander of the units involved in the My Lai incident, Maj. General Samucl W. Koster, was denoted and censured for failing to ascertain "the accuracy of the information which he had about My Lai." Washington Post, May 20, 1971, $\$$, at 1, cols. 3-4, at 12, col. 2. No criminal charges were preferred against officers, with the exception of Captain Mfedina, for failing to prevent or stop the massacre. Fourteen other officers were charged with covering-up or failing to investigate the incident, but only one-Colonel Oran Henderson-was brought to trial, and he was acquitted. Telford Taylor. United States Prosecutor at the Nuremberg Subsequent Proceedings, aptly concluded from this record that "the Army's procedures for the prevention, detection, and punishment of war crimes have failed abysmally." Taylor, The Course of Military Justice, N.Y. Times, Feb. 2, 1972, at 39, cols. 3-7. There is a large literature discussing "command influcnec" over prosecutorial decisions. See, e.g., note 84 infra.

66. Indeed, by conferring war crimes jurisdiction only upon military courts, whose jurisdiction over civilians is subject to very restrictive constitutional limits, Congress may have given non-military "commanders"-e.g. cabinet members and Defense Department and CIA officials-effective immunity from war crimes prosccution. See generally Toomepuu, Trial of American Civilians as War Criminals in American Courts, 31 FED. B.J. 73 (1972); Shaneyfelt, War Crimes and the Jurisdictional Afase, 4 INT'L LAwys. 924 (1970). 
II. Proposed Rules for Prospective Application in American Courts

\section{A. The General Case for "Strong" Rules of Command Responsibility, and an Exception}

\section{1. "Strong" Rules for American Commanders}

"Strong" rules of command responsibility have a mental standard of constructive (rather than actual) knowledge, recognize risks of future crime (rather than only specific crimes or criminal policies) as a mental object, and impose rigorous intervention duties subject to only narrowly defined excusing conditions. Their main advantage is straightforward: If rules influence command behavior, and subordinates obey their commanders, strong rules are more likely to reduce the incidence of subordinate crime. That subordinates typically obey is a basic tenet of military life. That officers will be influenced by consistently enforced rules on command responsibility is also plausible. While the proposed rules are somewhat complicated, officers as a class are reasonably well-educated, are normally expected to consult and execute detailed directives, and are typically anxious to maintain an unblemished career record by following all important rules. Further, while some of the duties created by the proposed rules may exceed intuitive moral obligations, they would never require defiance, but always a tightening, of normal hierarchical discipline. ${ }^{67}$

Adoption of strong rules would also improve the general reputation of the laws of war. Popular reaction to the Calley conviction revealed that war crimes law is distrusted in part because it strikes most harshly at low-level personnel, leaving virtually untouched the high-level officials who mold an army's attitudes and abilities, decide its tasks, and benefit most palpably from its successes. ${ }^{88}$ Strong rules on command responsibility, by distributing sanctions more equitably over the military hierarchy, might prevent popular feeling from rendering war

67. If, at the risk of severest immediate disciplinc, privates are required to disregard the illegal orders of their commanders, a commander should surcly be reculuircd to exert substantial efforts to frustrate illegal acts by his subordinates. Note that inilitary law already goes to extraordinary lengths in imposing affirmative duties on mere sol. diers to maintain order. All persons subject to the UCMJ, regardless of their rank, must do their "utmost" to prevent and suppress mutinies. MCM, para. 173(c), at 28.23.

68. Lt. William Calley was convicted on March 30,1971 , of murdering dozens of civilians in the My Lai Massacre. Reaction to the case was immediate and vociferous, much of it to the effect that Calley had been made a "scapegoat" for higher-ups. See, e.g., N.Y. Times, Mar. 30, 1971, at 12, cols. 1-2; id. Mar. 31, 1971, at 1, col. 2, at 18, cols. 4 ; id. Apr. 3, 1971, at 14, col. 3. 
crimes law a dead letter, or from supplementing it with political witchhunts against officials escaping regular legal processes. ${ }^{09}$

If provided with a strong and workable theory of vertical complicity, the laws of war could also safely jettison some of the dangerously broad notions of horizontal complicity developed in the post-war tribunals. ${ }^{\text {it }}$ Though differing in details, these notions share a common consequence: Whenever the normal functions of a military or civilian bureaucracy facilitate the perpetration of war crimes, a duty to mutiny, or at least to protest actively, is imposed on any member of the bureaucracy aware of the crimes, regardless of his hierarchical relationship to the perpetrators. ${ }^{11}$ As this duty rarely will be honored, it serves only

69. For example, Marcus Raskin has suggested that "militarists" and "imperialists" be purged from the American military and political bureaucracies through psetudo.judicial procedures based on the de-nazification programs which the United States operated in post-war Germany. Raskin, From Imperial Ifar-Making to a Code of Personal Resfonsibility, in R. Stavins, R. Barnet, ANd M. Raskin, Washington Plass AN iccressive WAR 255-374 (1971).

70. Horizontal complicity was broadly construed on three theorics. First, the claarters establishing various of the war crimes tribunals recognized "conspirac" or participation in a "common plan" as a basis for liability. See, e.g., Nuremberg Charter, Irt. 6(a), discussed in U.N. History, supra note 10 , at 196, and Regulation 8(ii), British Royal Warrant of June 14,1945, quoted in 1 UNLR 108. On the use of these theories in the Nuremberg trials, see Wasserstrom, supra note 51 . On their use in the Tokyo Trial, see J. KeEnan and E. Brown, Crimes Agaisst International LaW 88.112 (19j0). Second, tribunal charters occasionally "outlawed" whole organizations, such as the Nazi SS, and made participation in them a crime. See, e.g., Nurcmberg Charter, Arts. 9, 10, \& 11 , discussed in UN HIsToRY, supra, at 298-99. See generally' Jackson, The Law Under Which Nazi Organizations are Accused of Being Criminal, 19 TEs1. L.Q. 371 (1940): Wasserstrom, supra. Finally, the charters typically based simple complicity in criminal policies executed by an otherwise legal organization or by its leaders on a defendant's mere knowledge of the policies coupled with his normal participation in the organization. For example, Art. II(2) of Control Council Law No. 10, the "charicr" for the Nuremberg Subsequent Proceedings, quoted at $10 \mathrm{TWC}$ xix, imposed liability on any: one who "took a consenting part" or "was connected with plans or enterprises involving" or was a "member of any group or organization connected with the commission of" a war crime. See also the U.N. Commission's discussion of The Justice Trial, 6 UNLR 84-88.

Tribunals of course varied in their application of all these theories. but the logic of the theories allows rather startling conclusions. For instance, Wasserstrom, supra, reads the Nuremberg Charter to suggest that draftees into the United States anicel forces, even if remaining safely at a base in the United States, might be "chargeable with all the crimes committed by the armed forces in Vietnam." Id. at $45-46$.

71. This result follows logically if responsibility for crimes committed by the bureaucracy's leaders, or by others utilizing its resources, is imposed upon any member of the bureaucracy who is aware of the crimes and who continued to "serve" the burenucracy in a normal manner. Responsibility can be avoided under such a theory only by breaking or resisting bureaucratic routine, or by resigning; these altematives all amount to "mutiny" when; as is often the case in war-time, resignation and resistance are illegal.

In civilian criminal law, by contrast, the mens rea for complicity is usually "intent" or "purpose" to aid the perpetration, not merely "knowlcdge" of it. Sec, e.g., A.L.I. Mopet. Penal Code (Proposed Official Draft) $\$ 2.06(3)(\mathrm{a})$ (1962). Of course intent is usually inferable from the accused's knowledge of the perpetration coupled with his conduct facilitating the perpetration, but only because facilitation in a normal civilian setting requires stepping rather dramatically outside the cveryday routine of legal cnterprise. War crimes, however, are rarely separated neatly from the "legal" activities of the military or governmental bureaucracies in, through, or by means of which the crimes are committed. For instance, a janitor or clerk in the business office of a concentration camp does facilitate to some degree the crimes committed in the camp. In such cases, 
to lend an aura of fantasy to war crimes law and to give prosecutors nearly limitless discretion in selecting defendants. ${ }^{72}$

Against strong rules, three general arguments are conceivable. First, such rules might be claimed to inhibit the combat aggressiveness and effectiveness of officers. But the laws of war presume that a nation can adequately prosecute its campaigns without committing crimes. If this presumption is unsound, the proper response is a general weakening of war crimes law, not a selective cushioning of its impact on officers. Second, a strong rule might be claimed to deter "good men" from accepting military commissions and promotions. The short answer is that "good men" have, among other virtuous ambitions and abilities, the desire and capacity to maintain an army which is free of war crimes. Finally, it might be claimed that rules involving constructive knowledge and requiring the elimination of criminal risks must be so vague and broad as to encourage adjudication by caprice, hindsight, and prejudice. This objection is plausible, if only because some past cases involving strong rules have arguably been open to it. ${ }^{73}$ It can be answered, however, only by drafting strong rules which are comprehensible and capable of fair application.

\section{Exception: A Weak Rule for Enemy Commanders}

For several reasons, however, an enemy commander should be tried in American courts only under a weak rule of command responsibility. First, strong rules have heretofore been used only in American initiated and dominated tribunals. ${ }^{\tau+}$ There is room for doubt that "interna-

"intent" to aid in the crime-in the sense of a desire or purpose to do so-cannot be fairly inferred from the accused's knowledge of the crime coupled with his actual facilitation of it. To establish intent, the prosecution would probably have to show that the accused went qut of his way, or beyond "normal" routines, to facilitate the crime. It must be conceded that some war crimes tribunals, while jettisoning the tra. ditional "intent" standard, did require some "special" factors for conviction. "There was, for instance, a tendency to convict only the policy-makers and executives of the organizations involved in war crimes. See, e.g., The Belsen Trial, 2 UNLR 1, 119.20, and The Zyklon B Case, l UNLR 93, 120-22. Cf. also Trial of Pohl, 5 TWC 195, 1170. But no "narrow" theory of complicity was ever developed in a formal and satisfactory manner.

72. Such broad discretion might, of course, be thought useful in trials aimed primarily at convincing a conquered people of the errors of their leaders' ways. See, e.g., Trial of Pohl, 5 TWC 195, 1159. But theories of complicity must be much more pre. cisely defined to afford adequate guidance for genuinely "judicial" tribunals and fait warning to potential law breakers.

73. For criticism of some of the major command responsibility decisions of the post-war tribunals, see $R$. MiNEAR, supra note 12 , at $71-72 ; A$. REEL, supra note $4 ; \Lambda$. von Knieriem, The Nuremberg Trials, 196.99 (1959); and In re Yamashita, 327 U.S. 1, 26 (1945) (dissenting opinion of Mr. Justice Murphy).

74. Yamashita was tried by an American military commission. The Tokyo Tribunal, while having judges from several nations, was thoroughly dominated by the Americall occupation authority in Japan, under General Douglas A. MacArthur. See R. Minesk, supra note 12 , at $160-72$. 
tional law" fully recognizes strong rules, and American tribunals should not exceed that law in dealing with foreign defendants.

Second, pressure for revenge will in practice render any rule harsh and inflexible when applied to enemy military leaders, and provisions on constructive knowledge and elimination of risks invite special abuse in this context. When the defendant is American, by contrast, the extra-legal pressures will be toward leniency: Legal duties will be threatened not with an arbitrary expansion, but an arbitrary shrinkage.

Third, to determine fairly whether a commander has breached duties to investigate suspicious facts, to eliminate undue risks of future crime, or to intervene with "sufficient" vigor against specific crimes, criminal policies, or risks, a tribunal requires detailed information about the combat environment and the military hierarchy in which the defendant operated. Because enemy commanders will rarely be tried-because rarely captured-before the conclusion of hostilities, evidence will be stale or unavailable, and defendants will typically be joined into mass trials, where such information will necessarily receive imperfect attention. When trying American defendants, however, tribunals can avoid laundry list indictments and delayed justice by remaining in constant operation throughout a war. Testimony and evidence will be readily available, and rules can be given wide publicity to avoid unfair surprise.

Fourth, while strong rules can reform a nation's own military and administrative practices, they may increase the incidence of war crimes committed by an enemy. If faced with defeat, an enemy commander may resist more tenaciously-to the point of tolerating further subordinate crimes-when strong rules await him upon surrender or capture.

For all these reasons, only the first of the four rules proposed below should apply to enemy commanders, while American commanders should be subject to all of the rules. The first rule is a "weak" one, and each of the others strengthens it in a particular respect.

\section{B. The Rules}

\section{Rule One: Duty to Act Against Known Crimes} or Policies of Crime

If a commanding officer was actually aware that a particular war crime was being committed or planned by a subordinate, or that a unit of his subordinates was engaged in a policy of commitling war crimes, and if he made no attempt to prevent, arrest, or otherwise interfere with the commission of crime, or immediately to protest its commission to his superiors, he is an accomplice in said crime(s). 
Discussion: This rule requires only that a commander not stand mutely by as subordinates commit or plan crimes, or pursue criminal policies, of which he has actual knowledge. Because a tribunal trying a foreign commander is assumed to have only a sketchy appreciation of the circumstances under which he operated, the rule does not require a determination of whether the defendant's efforts were "reasonable" or "appropriate": Any good faith gesture against the crimes or policies, including a verbal protest to his superiors, will negate liability.

Neither this rule nor any of the others attempts to define commander status. For American defendants, Congress and the Executive can insure that the legal definition of commander status is consistent with the actual chain of command. For foreign commanders, no brief formula will be fully adequate. The tribunal should take care to honor the working realities of the enemy command structure. If a commander's conceded subordinates commit crimes at the specific order of his hierarchical superior, or commit crimes which he cannot suppress without violating superior orders, Rule One does require the commander at least to protest these crimes, or his inability to suppress them, to his superiors. No other result is fairly consistent with the similar international duty on ordinary soldiers to disobey illegal orders. But when the perpetrators are actually commanded in their illegal activities by an official belonging to another department or hierarchy, command responsibility should run to that official and not to the accused commander. While the law of war must occasionally require disobedience of national law and of superior orders, it is another matter to ascribe commander status to particular bureaucratic positions, e.g., cabinet "minister," not enjoying command authority in national law or practice over the subordinates in question. Given the myriad bureaucratic titles and organizational structures a nation might adopt, this would be an enormous project, and it seems at any rate both unfair and inefficient to use a criminal sanction on individuals, rather than such devices as multilateral treaties, to induce nations to conform their military, police, intelligence, and political structures to some international ideal.

\section{Rule Two: Duty to Prevent or Arrest Known Crimes or Policies}

(1) If a commanding officer was actually aware that a particular war crime was being committed or planned by a subordinate, or that a unit of subordinates was engaged in a policy of committing war crimes, and if he failed to prevent or arrest, as the case may be, the commission of crime, he is guilty of a war crime, provided that he is not guilty if 
$(A)(i)$ he reasonably believed himself physically unable to arrest or prevent completely the commission of crime, or (ii) he reasonably believed that he could not completely arrest or prevent the commission of crime without immediately risking death or serious injury to himself or his subordinates, or (iii) he reasonably believed he could not completely arrest or prevent the commission of crime without breaching superior orders or regulations, and if $(B)$ he exerted all efforts consonant with his physical and legal powers, and with the safely of himself and his subordinates, to arrest or prevent the commission of crime, and if $(C)$ he notified his superior officer without delay that his efforts might prove inadequate.

(2) No officer shall be prosecuted, punished, or disciplined for violating superior orders, for survendering his unit or ordering its retreat, or for endangering the life or safety of his subordinates if he believed these actions necessary to prevent or arrest the commission of war crimes by his subordinates.

Discussion: The mental elements are identical to those in Rule One. The intervention duty is much stronger but similarly avoids elastic normative terms such as "reasonable" or "appropriate." Rule Two requires successful prevention or suppression of subordinate crime unless one of the excusing conditions, $\$ \S(1)(\mathrm{A})(\mathrm{i})$ through $(\mathrm{l})(\mathrm{A})(\mathrm{iii})$, is met. Even when excuses apply, a commander must exert all efforts within the constraints of the excuse, i.e., not just "reasonable" efforts, $\S(1)(B)$, and must also immediately notify his superior of the possibility of failure, $\S(1)(C)$. (Notification of course raises Rule Two duties in the superior officer.) A duty to resign is avoided: Impractical in combat circumstances, such a duty might also encourage officers to "walk away" from on-going subordinate crimes or policies.

The excusing clauses, $\$ \S(1)(A)(i)$ through $(1)(A)(i i i)$, are phrased subjectively, i.e., in terms of the commander's reasonable beliefs. Whether the excusing conditions are objectively present may be unclear to a commander in some circumstances, and it seems unnecessarily harsh to require officers to guess correctly. Invocation of excusing conditions upon reasonable belief does not of course imply that the commander's intervention duty is limited to merely "reasonable" action. ${ }^{i 5}$

A commander may invoke a present inability to control his men,

75. The excusing clauses might be based on the accuscd's actual, as opposed to reasonable, belief, but then commanders might hesitate to challenge superior orders, and physical and combat obstacles, impeding their intervention against crime, aware that prosecutors could not easily prove the accused had not in fact believed that ex. cusing conditions were present in such circumstances. 
$\S(1)(A)(i)$, even if it stems from earlier defaults, such as his failure to train them properly. (Such prior delicts may, however, violate Rule Four, where a mental object of risks of future crime is recognized.) Excuse (1)(A)(ii) avoids the concept of "military necessity," which finds no clear stopping point if expanded beyond conventional notions of self-defense. The clause encompasses only danger to life and limb, not the peril of retreat or surrender. While tribunals may balk at punishing their own citizens for failing to meet a duty to retreat or surrender, without this duty command responsibility would evaporate whenever a unit encountered difficulties. Section (1)(A)(iii) provides a narrow excuse of superior orders. While an officer must of course disobey illegal superior orders, he should not be required to disobey legal orderse.g., schedules of attack-which in the circumstances hinder his suppression of subordinate crime. ${ }^{76} \mathrm{His}$ superior is typically better placed to evaluate the consequences of, and alternatives to, altering such orders, and the notification procedure ensures that the superior will quickly be put to this choice.

Section (2) of the Rule permits an officer to ignore excusing conditions and give absolute priority to crime suppression. Otherwise, officers and tribunals might interpret the excusing conditions too broadly, for an officer not availing himself of them would risk prosecution under conventional military law. Section (2) is phrased in terms of actual, not "reasonable," belief so as to maximize its protection of commanders who act boldly to prevent or arrest subordinate crimes.

\section{Rule Three: Duties to Know of Specific Crimes and Policies}

If a commanding officer is aware of particular facts indicating that his subordinates are committing or planning to commit war crimes, or that a subordinate unit is engaged in a policy of committing war crimes, and if he fails to draw reasonable inferences from those facts, or to make a diligent and thorough investigation of them, he shall be guilty of a war crime if such inferences or investigation would have revealed to him the commission of subordinate crimes or the existence of a subordinate criminal policy.

76. If the mental elements of Rule Two are met, a commander docs, however, have a duty to countermand or frustrate execution of illegal superior orders which by-pass him and issue directly to his subordinates. Because such countermanding would not violate any superior order binding on the commander himself, the excuse in $\$(1)(\Lambda)$ (iii) would be unavailable. His subordinates are under a duty to disobey the illegal order and are fairly entitled to the intervention and support of the "by-passed" coin. mander. Of course, any attempt to intervene would probably draw from the superior a new order to cease and desist. This new order, binding the commander personally, would fall within the terms of $\$(1)(A)(\mathrm{iii})$, and the commander would nced only to protest it, for it would not itself be illegal, e.g., an order to do an illegal act. But the commander could disobey it with impunity, because of $\S(2)$. 
Discussion: Rule Three merely applies a proper interpretation of constructive knowledge to the mental objects used in Rules One and Two. Absent duties to know, the existence of Rule Two's stiff intervention duties might discourage commanders from looking into suspicious circumstances and rumors concerning their subordinates' behavior. While Rule Two's intervention duties avoid general normative terms, Rule Three uses the terms "reasonable" and "diligent and thorough" because it is impossible to enumerate or classify the many circumstances and considerations which determine what inferences or investigations are justified by any "particular fact." The use of general normative terms here does not threaten serious inconsistencies in caseby-case adjudication, for questions of proper inference and investigation are less plagued by sharp value conflicts than is the question of how vigorously a commander "should intervene" against crime. Breach of these duties to know is actionable even if the officer-had he known of the pertinent mental object-could have invoked one of Rule Two's excusing clauses. This result is fair because none of the excuses entirely extinguishes a commander's intervention duties.

\section{Rule Four: Duty to Eliminate Non-Negligible \\ Risks of Future Crime}

If a commanding officer's subordinate commits a war crime while under his command, and if-prior to commission of the crime-it was unreasonable for the commanding officer to believe, on the basis of facts and circumstances of which he was aware, that there was only a negligible likelihood that such a war crime would be commitled, the commanding officer shall also be guilly of a war crime, provided that he shall not be guilty if, before commission of the crime, he nolified his superior officer that he believed a more-than-negligible likelihood existed that such a war crime would be commilted and that he believed himself incapable of reducing the likelihood to a negligible level, and provided further that a commanding officer not so notified shall not be guilty under this Rule for crimes commilled by other than his immediate subordinates.

Discussion: This rule attempts to meet four major problems raised by any duty to eliminate risks of future crime.

Definition of Unacceptable Risk. No matter how well managed, an army can never eliminate entirely the possibility that a war crime might occur. Rule Four thus speaks not of a zero, but of a "negligible" likelihood of future crime. The notion is not subject to precise defi- 
nition. The tribunal should assess, in essence, whether the type of war crime involved in the case could have been prevented by the command structure generally through better recruiting policies, better training, better leadership and discipline, or more prudent choice of strategy, tactics, or weapons. If it could, the risk of its commission was morethan-negligible. An army must select from available strategies, tactics, weapons, and procedures those which-whatever their relative costs and benefits in other respects-are least likely to induce or facilitate subordi. nate war crimes. This injunction is admittedly radical: It may mean that a nation cannot prosecute certain kinds of wars at a tolerable cost. ${ }^{77}$

But alternative definitions of "unacceptable" risks are unpersuasive. The post-war tribunals tried to distinguish acceptable from unacceptable risks by identifying the particular source or cause of the risk, i.e., by listing kinds of risk which are inherently or invariably excessive. ${ }^{78}$ This is an unpromising approach. A listing would need constant revision to keep up with changes in military tactics and weapons. Further, it is not clear that risks come in "kinds." Subordinate crime is typically risked by the coincidence of myriad discrete circumstances and factors, each of which might be of no concern were the others absent.

A rule might of course require intervention against only "unreasonable" or "gross" risks of crime, but such vague terms would allow each tribunal to weigh conflicting values differently, and officers would thus receive inadequate guidance from the law. Rule Four recognizes that a commander may reasonably believe risks to be negligible when in fact they are not, and indeed allows him to escape liability through a notification procedure even when he is aware risks are too high. Construing high risks of crime to be "acceptable" is neither necessary nor sufficient to ensure fairness to defendants.

Perception of Risk. The Rule implies a duty to intervene when the commander cannot reasonably believe risks are negligible, and intervention is adequate only if, in light of it, he can reasonably believe risks have been reduced to negligibility. Rule Four discourages com-

77. For example, it is conceivable that the United States could not have fought the Vietnam War at only a "negligible" risk of war crimes unless it had recruited its troops much more selectively, had abandoned use of heavy firepower, free-fire zoncs, and scarch. and-destroy missions, and had employed extremely expensive training programs. If so, regular enforcement of Rule Four, and regular use of its notification provision, would have placed liability in the President, or, at least, in the highest military commanders. That this probably would not have halted the war or brought a change in its methods, but rather only have led to repeal or disregard of the Rule, does not count against the Rule's adoption. It is better that law confront obviously reckless practice and suffer defeat than remain silent and imply that all is well.

78. See pp. 1282.84 supra. 
manders from isolating themselves generally from their subordinates: In judging the reasonableness of a commander's belief, the tribunal is to consider his actual state of knowledge, but his belief may be unreasonable even if no particular facts and circumstances known to him indicate the likelihood of criminal activity. Indeed the greater a commander's uncertainty and ignorance, the less reasonable would be his belief that risks of crime are below the benchmark of negligibility. ${ }^{70}$

The concept of "reasonable belief" tends to place responsibilities more frequently on low-level commanders: They are closer to the particular combat or field situation and thus have less reason to be ignorant of the risks raised "on the spot" by a confluence of factors from many sources. Also, lower-level officers are less often justified in assuming that other officers are carrying out measures to neutralize such risks. Rule Four reasserts the balance by providing the incentive of exculpation to those low-ranking officers who communicate their peculiar knowledge up the command hierarchy. The provision is not excessively generous to low-level officers. A notifying officer must admit inability to eliminate the risk, which may mar his service record, and he typically will receive from the notified officer detailed instructions to eliminate risks of crime. Violation of these instructions would of course be a conventional military offense.

The Divorce of Knowledge and Power. A line officer leading his men on a mission may know that their poor training, their low morale, and the exigencies of the mission raise unacceptable risks of crimebut he often will lack the power or legal authority to alter these factors. With Rule Four's notification provision, knowledge of risks will rise in the hierarchy to that point where sufficient power resides to eliminate the risk-in the example, to the officer with authority to cancel or modify the mission. If an officer chooses not to make a notification, Rule Four presumes conclusively that he has the physical ability and legal authority to eliminate all reasonably perceivable, non-negligible risks of subordinate crime.

If the Rule, instead of requiring notification, directly recognized excuses of physical inability, superior orders, or military necessityor required only "reasonable" or "feasible" intervention-it would pro-

79. To conclude reasonably that the risk of future crimes is only negligible, a com. mander must have considerable information about precautions taken against such risk. Note, by contrast, that under Rule Three a commander may safely assume that crimes are not presently occurring if he is unaware of particular facts indicating the contrary. Behind this distinction are the simple assumptions that criminal activity is the exception but that, over the long run, such activity will almost surely break out unless precluded by precautions and safeguards. 
vide no incentive to eliminate risks where knowledge was divorced from power. A rule could attempt to wed knowledge to power by requiring only that commanders not create risks of subordinate crime. But the ever-troubled distinction between acts and omissions is peculiarly difficult to apply to command behavior, which typically consists of complex reactions to fluid situations. Further, since risks of crime have many causes, a commander may contribute to a risk without having reason to know he has done so, and those who cause a risk are not necessarily well-placed to eliminate it quickly and efficiently. Consistent enforcement of the Rule will induce the military itself to locate and remedy those basic defects which give rise to unacceptable risks of subordinate crime.

Multiplicity of Defendants. In some instances a risk will be reasonably perceivable at many levels of the command hierarchy. Upon occurrence of subordinate crime-unless all officers except the highest in rank had "notified" their superiors-the prosecutor would have a long list of possible defendants, and his choice among them would involve criteria never fully advertized and very likely inconsistent from case to case.

To meet this problem, Rule Four limits prosecution to commanders who either have received notification or are in immediate charge of the subordinate committing the war crime. This of course places the obligation to eliminate risks initially upon the immediate superior of the perpetrator. The provision ensures rapid countermeasures against risks and a heavy flow of vital information up the hierarchy. Also, that high-level officers will typically be tried only if they have received notification from below will greatly simplify adjudication. The notifications will themselves constitute prima facie evidence that the officer knew of the unacceptable risk, and the sole question will be whether the defendant's actions subsequent to notification were such as to rencler reasonable his belief that the risk had become only negligible. ${ }^{80}$

\section{Penalties}

Under Rule One, which defines command responsibility as a form of complicity, punishment may equal that imposed on the subordinate

80. If, instead, prosecution began with the highest ranking commander of the sub. ordinate perpetrator, each subordinate crime would result in trials of the same high. level commanders, and many trials would typically be required before a conviction was attained. If the prosecution were instructed to try the commander who had been "best able" to eliminate the subordinate crime, the courts would bccome entangled in weighing the relative merits and costs of various means of crime suppression.

Note that the proposal in the text narrows-but does not entirely eliminate-prosecu. torial discretion as to defendant, for in any particular case there may be several commanders who have received notifications. 
perpetrator. This is fair because the command omission criminalized in such a case is a clear moral default. For breach of the other rules, however, penalties should be quite minor, perhaps only fines and demotions. The moral status of the delicts involved is debatable, and high potential penalties might discourage regular and vigorous enforcement. Given such enforcement, the penalties need not be draconian to influence the behavior of career-conscious officers. But, however small, the penalties should be imposed only by formal and publicized proceedings: To have effect, the rules must be widely understood and seen to be fair both in theory and practice.

\section{Conclusion: Routes to Reform}

No international legislature exists to enact these rules, and there is no international criminal court to adopt them as a "clarification" of existing law. For the foreseeable future, the laws of war must be reformed through the experiments of individual nations.

The rules might become applicable in American courts in several ways. Military judges might adopt them as plausible interpretations of the Law of War under Article 18 of the UCMJ, but this is an unpromising route to reform. Even if the evolution of war crimes law through a common law process were permitted by the Constitution and facilitated by a steady flow of cases, rules of the precision and detail outlined above would take years to develop. Furthermore, the proposed rules do not pretend accurately to "restate" the international precedents, but aim rather to replace these with a coherent set of new guidelines. Judicial adoption of the rules as an interpretation of the Law of War would leave unsettled the conflict between Article 18 and the several specific crimes created elsewhere in the UCMJ. And the military judiciary could not on its own eliminate command influence over prosecution procedures or institute the prosecution priorities proposed in Rule Four.

Presidential adoption of the rules, while perhaps feasible, also has drawbacks. The President might simply issue the rules as a general regulation, binding on military officers as a superior order, or he might promulgate them as part of the Manual on Courts-Martial, which provides detailed interpretations of UCMJ offenses. The latter procedure risks constitutional problems: The Manual can only suggest interpretations of existing crimes, not create new ones. ${ }^{81}$ The proposed rules

81. See Reid v. Covert, 354 U.S. 1, 38.39 (1957 and Note, Taps for the Real Catch-22, 81 YALE L.J. 1518, 1523-24 (1972). 
arguably go beyond the international Law of War incorporated in Article 18, and almost certainly exceed specific Code provisions relating to command responsibility. Issuing the rules as a general regulation might avoid this constitutional obstacle. ${ }^{82}$ But command influence over prosecution would remain, and the prosecution priorities under Rule Four would have an uncertain status. Rather than resolving the conflict between Article 18 and other Code provisions, a general regulation would provide yet another theory for punishing command delicts, and penalties under this theory would not be graduated according to the rule breached-all breaches constituting "disobedience" of a lawful order. ${ }^{83}$ Finally, the President is himself subject to command responsibility under international law, and the formulation of applicable standards should not be left to an interested party.

Congressional codification of the rules, as an amendment to the UCMJ, would meet all of these problems. Such action could simultaneously resolve the conflict between Article 18 and specific Code provisions. Several bills have been proposed to establish a prosecutorial agency for military crimes independent of command influence; ${ }^{84}$ these could be readily amended to cover war crimes and to establish the prosecution priorities in Rule Four. Congressional hearings would provide the open deliberation, and extensive solicitation of expert testimony, which should precede such a major reform.

There is of course no reason for Congress to restrict its attention to the law on command responsibility. The Indochina experience has revealed many other defects in war crimes law and in the procedures established to enforce it. ${ }^{85}$ The country has understandably rejected an orgy of war crimes trials as a proper remedy for these defects. But prospective action remains possible. If the lessons of Indochina are simply forgotten, future generations may be taught them afresh.

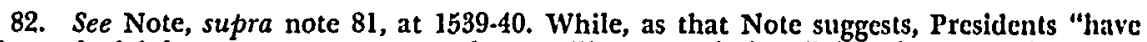
always had inherent power to promulgate military regulations," id., there remains room for doubt that this power can be used to create elaborate new criminal offenses.

83. Such disobedience would violate Art. 92(1), U.C.M.J., 10 U.S.C. \$ 892(1) (1970), for which the maximum penalty is two years imprisonment. MCM, Table of Maximum Punishments, para. 127c, at 25.12.

84. See, e.g., S. 987, 93d Cong., 1st Sess. (1973) and S. 1127, 92d Cong., 1st Sess. (1971). For discussion of the issues involved see Bayh, The Military Justice Act of 1971: Thic Need for Legislative Reform, 10 AM. CRIM. LAw REv. 9 (1971); De Giulio, Command Control: Lawful Versus Unlawful Application, 10 SAN Dieco L. REv. 72 (1972); Hodson, Courts-Martial and the Commander, id. at 51; Quinn, Prosecutorial Discretion: An Overview of Civilian and Military Characteristics, id. at $\mathbf{3 6 .}$

85. Among the many areas in need of reform are jurisdictional matters, see note 66 supra, notions of horizontal complicity, see pp. 1293.94 supra, the concept of military necessity, see note 41 supra, and the legal status of heavy bombing and artillery strikes in or near populated areas, see $T$. TAYLoR, Nuremberg and Vietnam: AN AMERICAN TRAGEDY 140.45 (1970). 